\title{
Effects of different levels of potassium fertilization on yield, quality and storage life of onion (Allium cepa $\mathrm{L}$.) at Jimma, Southwestern Ethiopia.
}

\author{
Muluneh Bekele* \\ Department of Horticulture, College of Agriculture, Samara University, Samara, Ethiopia
}

\begin{abstract}
In Ethiopia the yield of Onion (Allium cepa L.) is far below the national standards owing to several factors; absence of location specific fertilizer recommendation being the major among others. Thus, field and laboratory experiments were undertaken at Jimma in collaboration with Jimma University, Department of Post-harvest Management. Potassium sulphate fertilizer as TSP was used at $0,40,80$ and $120 \mathrm{~kg} \mathrm{ha}^{-1}$ levels with three replications. GenStat 12.1 version computer software packages were employed to analyze the data. From the results potassium fertilizer application at different levels showed significant effects on growth, yield and quality parameters i.e. Plant height, leaf length, leaf number, sheath length, bolters percentage, days to maturity, harvest index, mean bulb weight, bulb length, bulb diameter, TSS ( ${ }^{\circ}$ Brix), DMC (\%) and bulb shape index. Similarly, keeping quality of the onion bulbs including bulb sprouts $(\%)$, weight loss $(\%)$, weeks to $50 \%$ bulb sprouts and storage rots $(\%)$ were highly influenced by application of $\mathrm{K}$ at different levels. Maximum $\left(120 \mathrm{kgha}^{-1}\right)$ application of potassium significantly decreased bulb rots $(\%)$, bulb sprouts $(\%)$, weight loss $(\%)$ and prolonged weeks to $50 \%$ bulb sprout during the two month storage time at ambient storage temperature and humidity. This could be recommended for the uses by potential onion investors or farmers in the study area. Nevertheless, more researches are needed in different locations and on different soils in various season to come up with specific soil test based fertilizer recommendation.
\end{abstract}

Keywords: Fertilization, Growth, Jimma, Onion, Potassium, Quality, Storage life, Yield.

Accepted on August 30, 2018

\section{Introduction}

Onion is an important vegetable crop worldwide, ranking second among all vegetables in economic importance next to Tomato. Onion contributes significant nutritional value to the human diet and has medicinal properties and is primarily consumed for their unique flavor or for their ability to enhance the flavor of other foods [1]. The primary center of origin for Onion is Central Asia with secondary center in Near East and the Mediterranean region. From these centers, the Onion has spread widely to other many countries of the world [2]. Onion is different from the other edible species of alliums for its single bulb and is usually propagated by true botanical seed.

According to FAO [3] among the onion producers, the first is China in terms of area of production. The highest productivity is from Korea Republic (67.25 t/ha) followed by USA (53.91 $\mathrm{t} / \mathrm{ha}$ ), Spain (52.06 t/ha) and Japan (47.55 t/ha). India being the second major Onion producing country in the world has a productivity of $10.16 \mathrm{t} / \mathrm{ha}$ only. Onion was introduced to the agricultural community of Ethiopia in the early 1970's when foreigners brought it in. Though shallots were traditional crop in Ethiopia, Onion is becoming more widely grown in recent years.

Different cultural practices and growing environments are known to influence yield and quality of dry bulb. So far, research in the country was mainly focused on the identification of superior cultivars of onions and adopting improved management practices. Mineral nutrition is main that affects yield and quality of onion [4]. Nitrogen and Phosphorus and Potassium are often referred to as the primary macronutrients because of the probability of plants being deficient in these nutrients and because of the large quantities taken up by plants from the soil relative to other essential nutrients [5]. Nitrogen comprises $7 \%$ of total dry matter of plants and is a constituent of many fundamental cell components [6]. It is one of the most complexes in behavior, occurring in soil, air and water in organic and inorganic forms. For this reason, it poses the most difficult problem in making fertilizer recommendations [7]. Plant demand for $\mathrm{N}$ can be satisfied from a combination of soil and fertilizer to ensure optimum growth.

In Ethiopia, so far there was a general understanding that Ethiopian soils are rich in $\mathrm{K}$ and there was no need for its application based on the research conclusion of some 50 years ago [8]. However, research report indicated that $\mathrm{K}$ is removed through deforestation, crop export, leaching of cations and other possible reasons, especially in some highland areas of Southern Ethiopia and possibly in other similar areas of the country [9]. Similarly, a significant higher bulb yield (247.79 q ha-1) and fresh bulbs weight (49.53 g) were registered with application of $150 \mathrm{~kg} \mathrm{~K} \mathrm{ha}{ }^{-1}$ over other levels. Worldwide, post-harvest losses in fruits and vegetables range from 24 to $40 \%$ or even greater, reaching up to $50 \%$ in developing tropical countries [10]. A 
post-harvest loss in onion has been estimated to reach $30 \%$ in Sudan [11] and 50 to $76 \%$ in Nigeria [12]. A comprehensive statistics for such losses is not available for Ethiopia.

However, Proper management techniques such as fertilizers, soil moisture and disease control, harvest time and curing enhance Onion produce [13]. Optimization of such practices results in significant decrease in post harvest losses and increase bulb yield in Onion. Decrease in post harvest losses will be instrumental in market stability and exploiting opportunities to export Onion and earn foreign exchange. Best quality Onion can be produced through application of well balanced fertilizers [14].

In general, better understanding of the nutrient requirements of onion plant is needed in order to develop management strategies, which optimize fertilizer use of the crop and thereby increase returns with premium bulb qualities to the producers. In the light of the above aspects, the present research was initiated to identify the economical level of potassium fertilization for onion (Allium cepa L.) optimum growth, yield, and quality and storage life under Jimma conditions, Southwestern Ethiopia.

\section{Literature Review}

\section{The onion crop}

Onion being a biennial crop, takes two seasons for seed production, but mainly it is grown for bulbs; although the green shoots of salad onion is also an important part. Drained friable loam soil with a $\mathrm{pH}$ of 6.0 to 6.8 is good for better yield [15]. The Onion bulb consists of the swollen bases (sheaths) of bladed leaves surrounding swollen bladeless leaves. Each leaf consists of a blade and sheath. Collectively, the grouping of these sheaths comprises the pseudostem. Leaves arise from the short, compressed, dislike stem which continues to increase in diameter with maturation and resembles an inverted cone. The onion skin is formed from the dry paper like outer most leaf scales that lose their freshness during bulbing. Major bulb features are uniformity of shape, size and skin color, pungency and dry matter content [16].

\section{Agronomic characteristics of onion}

The onion root system is fibrous, spreading just beneath the soil surface to a distance of 30 to $46 \mathrm{~cm}$. It has few laterals, and total root growth is sparse and not especially aggressive. Competition from aggressive root systems (as from weed growth) severely limits onion growth [17]. In Ethiopia Onion can grow from sandy loam to heavy clay, but it prefers well drained sandy loam. Due to build up of soil borne diseases, it should be rotated with unrelated crops such as beans, and cereals. Onion could be planted at an interval of 3 to 4 years [18]. The best growing altitude for onion in Ethiopian is from 700-2200 m.a.s.l and the optimum growing temperature ranges between $15^{\circ} \mathrm{C}$ and $23^{\circ} \mathrm{C}$ $[19,20]$.

Onion dry bulb can be produced throughout the year if dependable irrigation water, and diseases and insect pests control measures are available. However, the yield of onion is vary from season to season due to diverse climatic conditions prevailing in the production areas. Findings of the research done by Melkassa Agricultural research center at the upper Awash rift valley revealed that $20 \mathrm{~cm}$ between rows on the bed and $10 \mathrm{~cm}$ between plants with 333,300 plants $\mathrm{ha}^{-1}$ gave high yield $(150 \mathrm{q} / \mathrm{ha})$ and was easy to manage the plant. This is suitable for small-scale hand operated production system for the Melkassa and other areas with similar agro-ecologies. The spacing could be adjusted depending on the availability of facilities especially for tractor operated large scale production [18].

\section{Climatic requirements of onion crop}

Onion requires moist soil throughout the growing period. Moderate rainfall is preferable since excessive soil water and high humidity encourage diseases. The optimum water requirement for yield is between 350 to $550 \mathrm{~mm}$ of water [21] A cool period promotes early leaf development, while high temperatures encourage bulb development but flower and seed production is only possible where the bulbs are subjected to low temperatures. Bulb setting in any onion variety is determined by day length and temperature. The optimum temperature for bulb setting is 20 to $25^{\circ} \mathrm{C}$. At 10 to $15^{\circ} \mathrm{C}$ bulbs do not develop well regardless of day length. Temperature can also have another effect on plant development, and therefore production. Once an onion plant reaches a certain physiological age (50 to 80 days old) it may respond to certain temperature conditions (below 14 to $10^{\circ} \mathrm{C}$ ) by initiating a flower head, which then develop flower stalk up to $1 \mathrm{~m}$ high.

\section{Potassium nutrient requirements of onion crop}

Potassium plays a pivotal role in plant growth and development. Like other vegetable crops, onion is very responsive to potassium fertilization. It has a crucial role in the energy status of the plant, translocation and storage of assimilates and maintenance of tissue water relation. Also K plays a key role of crop quality. It improves size of fruit and stimulates root growth. It is necessary for the translocation of sugars and formation of carbohydrates.

According to report by Madan and Sandhu [22] the trials with Onion cv. Punjab 48 with the application of $185: 117: 105 \mathrm{~kg}$ $\mathrm{N}, \mathrm{P}_{2} \mathrm{O}_{5}$ and $\mathrm{K}_{2} \mathrm{O}$ ha- ${ }^{-1}$ gave the maximum bulb yield. Similarly, Singh and Dankhar [23] also noticed that application of K alone and in combination with zinc $\left.\left(100 \mathrm{~kg} \mathrm{~K} \mathrm{~K}_{2} \mathrm{O}+25 \mathrm{~kg} \mathrm{ZnSO}\right)_{4}\right)$ increased plant growth $(61.62,64.9 \mathrm{~cm})$ yield and dry matter of bulbs (15.05 $\mathrm{g}$ and $14.9 \mathrm{~g}$ ), respectively. Onion dry matter production, bulb size and bulb yield increased with the increase in levels of $\mathrm{K}$ from 0 to $150 \mathrm{~kg} \mathrm{ha}^{-1}$ as reported by Salimath [24]. The similar results again observed by a study [25] that significant differences among the fertilizer doses with respect to Onion plant height. Plants were the tallest when $90 \mathrm{~kg} \mathrm{~N}$ and $120 \mathrm{~kg} \mathrm{~K}_{2} \mathrm{O} \mathrm{ha}^{-1}$ were applied. Again, a study [26] also recorded that the higher number of leaves per plant $(11.56,11.68)$, weight of bulb (50.42 from $51.83 \mathrm{~g}$ ) and bulb yield (226.66 from 227.66 $\mathrm{q} / \mathrm{ha}$ ) with increase in Potassium application from 100 to $150 \mathrm{~kg}$ $\mathrm{ha}^{-1}$.

The increase in $\mathrm{K}$ application significantly increased the dry weight of tops and bulbs, bulb diameter, 100 bulb weight and bulb yield up to $40 \mathrm{~kg} \mathrm{~K}_{2} \mathrm{O} \mathrm{ha}^{-1}$ [27]. The application of fertilizers at $\mathrm{RDF}\left(125 \mathrm{~kg} \mathrm{~N}, 33 \mathrm{~kg} \mathrm{P}_{2} \mathrm{O}_{5}\right.$ and $\left.50 \mathrm{~kg} \mathrm{~K}_{2} \mathrm{O} \mathrm{ha}^{-1}\right)$ and $150 \%$ RDF (187 kg N, $49 \mathrm{~kg} \mathrm{P}_{2} \mathrm{O}_{5}$ and $75 \mathrm{~kg} \mathrm{~K}_{2} \mathrm{O} \mathrm{ha}^{-1}$ ) registered 42 and $56 \%$ increases in bulb yield of onion, respectively over $50 \%$ NPK dose [28]. In similar way a study [29] also noticed 
that a significantly higher yield of bulb (247.79 $\left.\mathrm{q} \mathrm{ha}^{-1}\right)$ and fresh weight of bulbs (49.53 g) with application of $150 \mathrm{~kg} \mathrm{~K}_{2} \mathrm{O}$ $\mathrm{ha}^{-1}$ over other potassium levels. Increased bulb yield of garlic (97.24 $\mathrm{q} \mathrm{ha}^{-1}$ ) was obtained with 150:80:50 kg N, $\mathrm{P}_{2} \mathrm{O}_{5}$ and $\mathrm{K}_{2} \mathrm{O}$ $\mathrm{ha}^{-1}$ application. However, considering economics of crops balanced use of $\mathrm{N}, \mathrm{P}_{2} \mathrm{O}_{5}$ and $\mathrm{K}_{2} \mathrm{O}$ fertilizers at 100:40:50 gave optimum returns [30]. The application of Potassium at $125 \mathrm{~kg}$ $\mathrm{ha}^{-1}$ recorded significantly highest plant height, total dry matter production which was on par with $150 \mathrm{~kg} \mathrm{ha}^{-1}$. Same treatment recorded significantly higher bulb weight (106.44 g/plant), bulb length $(4.68 \mathrm{~cm})$, bulb diameter $(5.32 \mathrm{~cm})$ and bulb yield $(22.87$ $\mathrm{t} / \mathrm{ha}$ ) over control [31].

In Ethiopia, the study conducted at Jimma in comparing $\mathrm{N}$ and $\mathrm{P}$ with $\mathrm{N}, \mathrm{P}$ and $\mathrm{K}$ application on potato indicated that the tuber yield of potato was increased from $11.77 \mathrm{t} / \mathrm{ha}^{-1}$ in the N-P treatments to $34.93 \mathrm{t} / \mathrm{ha}^{-1}$ in the N-P-K treatments, which means N-P-K application increased the tuber yield by $197 \%$ over the $\mathrm{N}-\mathrm{P}$ treatments suggesting that $\mathrm{K}$ is critically deficient in the area and disproved the long standing conclusion by Murphey that Ethiopian soil are rich in potassium [9]. Potassium nutrient is an essential nutrient which is vital in photosynthesis activity of leaf, as it helps in translocation of food. Besides, plants require large amount of $\mathrm{K}$ than the soil can supply. Generally, onion takes up potassium nutrient in quantities nearly equivalent to $\mathrm{N}$ [32-34].

\section{Material and Methods}

\section{Description of the experimental site}

The field experiment was conducted at Jimma under irrigation condition. Before planting the analysis of soil samples from the top $30 \mathrm{~cm}$ depth was done and indicated in Table 1 .

\section{Experimental materials}

Onion (Allium cepa L.) variety Bombay Red which is released by Melkassa Agricultural Research Center in 1980 through selection was used as a planting material for the study (Table 2).

\section{Experimental design and layout}

Onion seedlings were raised in the nursery on a well prepared seedbed whose dimension was $5 \mathrm{~m} \times 1 \mathrm{~m}$. The seeds were sown in rows marked $15 \mathrm{~cm}$ interval across the length of the seed bed and the beds were covered with dry grass mulch until emergence. Complete germination of the seeds took place within 7 to 10 days of sowing and seedlings were thinned out after three weeks in order to maintain optimum plant population and to keep them vigorous. Watering of the seed bed was done always in the morning and afternoon using watering can. The seed beds were

Table 1. Soil physical and chemical properties of the experimental site.

\begin{tabular}{|c|c|}
\hline Characteristics & Status \\
\hline Sand (\%) & 8 \\
\hline Silt (\%) & 44 \\
\hline Clay (\%) & 48 \\
\hline Textural class & Silty clay \\
\hline Organic carbon (\%) & 1.46 \\
\hline Exchangeable K & $0.83 \mathrm{meq} / 100 \mathrm{~g}$ \\
\hline $\mathrm{pH} 1: 1$ water & 5.94 \\
\hline Electric conductivity $(1: 1)$ & $53.1(\mu \mathrm{S} / \mathrm{cm})$ \\
\hline Bulk density $\left(\mathrm{g} / \mathrm{cm}^{3}\right)$ & 1.58 \\
\hline
\end{tabular}

Table 2. Details of the onion variety used in the study.

\begin{tabular}{|c|c|c|c|c|c|}
\hline \multirow{2}{*}{$\begin{array}{l}\text { Variety } \\
\text { Name }\end{array}$} & \multirow{2}{*}{$\begin{array}{l}\text { Year of } \\
\text { Release }\end{array}$} & \multicolumn{2}{|c|}{ Area of adaptation } & \multirow{2}{*}{$\begin{array}{l}\text { Days to } \\
\text { maturity }\end{array}$} & \multirow{2}{*}{$\begin{array}{l}\text { Yield } \\
\text { (t/ha) }\end{array}$} \\
\hline & & $\begin{array}{l}\text { Altitude } \\
\text { (m) }\end{array}$ & $\begin{array}{l}\text { Rain fall } \\
(\mathrm{mm})\end{array}$ & & \\
\hline $\begin{array}{l}\text { Bombay } \\
\text { Red }\end{array}$ & 1980 & $700-2000$ & Irrigated & $<120$ & $25-30$ \\
\hline
\end{tabular}

watered before uprooting the seedlings in order to minimize the damage of the roots. Healthy, uniform and 51 days old seedlings were transplanted to the prepared field at spacing according to the EARO, 2004 recommendation. All the twelve treatment combinations were randomly assigned and there were 10 plants in each row and 60 plants per plot with three replications. During the course of the study Mancozeb was applied to prevent the damage of disease at rate of $4.0 \mathrm{~kg} \mathrm{ha}^{-1}$ mixed in 600 liter of clean water. All other agronomic management practices were provided as per the recommendation equally for all the treatments [35].

Finally, bulbs from the central four rows were harvested after $60 \%$ neck-break and used for analysis. Curing of bulbs was done for ten days under partial shade and ten sample bulbs were used for storage. Naturally ventilated house was constructed from wire mesh wall and corrugated iron sheet roofing then kept in boxes made of wire mesh to record data on storage life of onion bulb. Daily storage room temperature and relative humidity was recorded using digital sling Psychrometer (AZ8706 model, China). The storage time was from the month of May to July for three months under the average monthly temperatures and relative humidity of $17.23^{\circ} \mathrm{c}$ and $16.72^{\circ} \mathrm{c}, 75.32 \%$ and $77.65 \%$, respectively.

\section{Statistical analysis}

The data were analyzed using GenStat versions 12.1 (2009) with the REML variance component analysis. Mean differences were tested following least significant difference (LSD) at $(\mathrm{P} \leq 0.05)$.

\section{Results}

\section{Growth parameters}

Plant height: Main application of $\mathrm{K}$ had shown a highly significant $(\mathrm{p}<0.001)$ difference on mean plants height at physiological maturity (Table 3 ). The maximum mean plants height $(48.37 \mathrm{~cm})$ was recorded in the plots that received $\mathrm{K}$ at $120 \mathrm{~kg} \mathrm{ha}^{-1}$, while the minimum $(44.82 \mathrm{~cm})$ was observed in the unfertilized plots. Increasing the level of applied $\mathrm{K}$ from 0 to $120 \mathrm{~kg} \mathrm{ha}^{-1}$ increased the mean plants height by about $7 \%$ as compared to the control. Similar results reported that application of $\mathrm{K}$ at $125 \mathrm{~kg} \mathrm{ha}^{-1}$ had showed significantly the highest plants height in onion [31]. There are also many other investigators who reported that an increase in vegetative growth with increased potassium fertilization levels on sweet pepper, egg plant, tomato and muskmelon [36-41].

Number of leaves per plant: The number of leaves is an important yield component. Leaves manufacture food with the help of chlorophyll and translocate it down for bulb development. Leaf number per plant at physiological maturity was highly and significantly $(\mathrm{p}<0.001)$ affected by application of K (Table 3). The plots that were fertilized with the maximum rate of $\mathrm{K}\left(120 \mathrm{~kg} \mathrm{ha}^{-1}\right)$ showed about $14.7 \%$ increase in mean 
Citation: Bekele M. Effects of different levels of potassium fertilization on yield, quality and storage life of onion (Allium cepa L.) at Jimma, Southwestern Ethiopia.. J Food Sci Nutr. 2018;1(2):32-9.

number of leaves per plant which is statistically the same with value $(14.2 \%)$ registered from plots that received only $80 \mathrm{~kg}$ $\mathrm{ha}^{-1}$. Further application of $\mathrm{K}$ above $80 \mathrm{~kg} \mathrm{ha}^{-1}$ did not bring change on onion mean number of leaves per plant. However, the minimum result (8.93) was recorded in the control treatment. There is a similar report that the higher number of leaves per plant $(11.56,11.68)$, weight of bulb (50.42 from $51.83 \mathrm{~g})$ and bulb yield (226.66 from $227.66 \mathrm{q} / \mathrm{ha}$ ) with increase in Potassium application from 100 to $150 \mathrm{~kg} \mathrm{ha}^{-1}$ [26].

Leaf length: Potassium fertilizers application at different levels showed a highly significant $(p<0.001)$ effect on the mean leaf length per plant (Table 3 ). The plots that were fertilized with the maximum rate of $\mathrm{K}\left(120 \mathrm{~kg} \mathrm{ha}^{-1}\right)$ showed about $8 \%$ increase in mean leaf length per plant which is statistically the same with value $(7.01 \%)$ registered from plots that received only $80 \mathrm{~kg}$ of $\mathrm{K} \mathrm{ha}^{-1}$. Further application of $\mathrm{K}$ above $80 \mathrm{~kg} \mathrm{ha}^{-1}$ did not bring change on onion mean leaf length. However, the minimum mean leaf length $(35.0 \mathrm{~cm})$ was recorded in the control treatment. This result is correlated with the report of a study [37] indicated that mean leaf length of onion plants increased with increased $\mathrm{K}$ application. Similarly [25] also reported that as there is a significant difference among the fertilizer doses with respect to Onion plant height. Plants were the tallest when $90 \mathrm{~kg} \mathrm{~N}$ and $120 \mathrm{~kg} \mathrm{~K}_{2} \mathrm{O} \mathrm{ha}^{-1}$ were applied.

Leaf sheath (shaft) length: The mean leaf sheath length of Onion is highly influenced with application of different levels of K (Table 3). However, further application of $\mathrm{K}$ above $80 \mathrm{~kg}$ $\mathrm{ha}^{-1}$ did not bring change. Application of $\mathrm{K}$ up to $80 \mathrm{~kg} \mathrm{ha}^{-1}$ increased the mean leaf sheath length by about $12 \%$ compared to the control treatment $(5.49 \mathrm{~cm})$. In Similar there is a report that potassium deficiency may lead to a reduction in number and size of individual leaves produced, which is also the same for the mean leaf sheath length [42].

Days to physiological maturity: Application of $\mathrm{K}$ had shown a highly significant $(\mathrm{p}<0.001)$ difference on days to physiological maturity. Potassium fertilizers application at the rates of $80 \mathrm{~kg}$ $\mathrm{ha}^{-1}$ delayed the days to attain physiological maturity by about three days; while further application of $\mathrm{K}$ above $80 \mathrm{~kg} \mathrm{ha}^{-1} \mathrm{did}$ not increase the days to attain physiological maturity and the graph started to decline.

\section{Yield parameters}

Bulb diameter and bulb length: Results from Table 4 below indicated that, $\mathrm{K}$ application showed a highly significant difference on both the mean bulb diameter and bulb length of onions. Statistically the highest mean bulb diameter and length were observed in plot at rate of $80 \mathrm{~kg} \mathrm{ha}^{-1}$ and at $120 \mathrm{~kg} \mathrm{ha}^{-1}$. The results again showed that further application of $\mathrm{K}$ above 80 $\mathrm{kg} \mathrm{ha}^{-1}$ did not bring any additional increase in both mean bulb length and diameter. On the other hand for both parameters the lowest records were observed in the unfertilized plot. Similarly, there is a report that potassium application at $125 \mathrm{~kg} \mathrm{ha}^{-1}$ showed higher bulb length and bulb diameter when compared with control [31] (Table 4).

This findings are in line with the reports that the higher number of leaves per plant $(11.56,11.68)$, weight of bulb $(50.42$ from $51.83 \mathrm{~g}$ ) and bulb yield (226.66 from $227.66 \mathrm{q} / \mathrm{ha}$ ) with increase in Potassium application from 100 to $150 \mathrm{~kg} \mathrm{ha}^{-1}$ [26].

Similarly, a study [27] observed that the increase in K application significantly increased the dry weight of tops and bulbs, bulb diameter, 100 bulb weight and bulb yield up to $40 \mathrm{~kg} \mathrm{~K}_{2} \mathrm{O} \mathrm{ha}^{-1}$.

Mean bulb weight: There was statistically highly significant $(p<0.001)$ difference encountered in mean bulb weight due to application of $\mathrm{K}$ at different levels. Of all levels considered in the study, application of $\mathrm{K}$ at a rate of $120 \mathrm{~kg} \mathrm{ha}^{-1}$ increased the mean bulb weight values by about $16 \%$ over control treatments ( $40.94 \mathrm{~g})$. The increase in mean bulb weight with the supply of $\mathrm{K}$ fertilizer nutrients could be due to more luxuriant growth, more foliage and leaf area and higher supply of photosynthates which helped in producing bigger bulb, hence resulting in higher yields. Similar results are reported that a significantly higher yield of bulb (24.7 ton ha ${ }^{-1}$ ) and fresh weight of bulbs (49.53 g) with application of $150 \mathrm{~kg}$ of $\mathrm{K}_{2} \mathrm{O} \mathrm{ha}^{-1}$ over other potassium levels [29].

Marketable bulb yield: The results from Table 5 below indicated that as $\mathrm{K}$ application is resulted in a highly significant $(\mathrm{p}<0.001)$ difference in marketable bulb yield. Among all levels of treatment the application of $\mathrm{K}$ at $120 \mathrm{~kg} \mathrm{ha}^{-1}$ increased the marketable bulb yield by about $47 \%$ as compared with the control treatment (12.96 ton ha-1) (Table 5).

Table 3. Mean effect of potassium on mean plant height, leaf length, leaf number and neck length.

\begin{tabular}{|c|c|c|c|c|}
\hline Treatments Potassium (kg ha-1) & Plant height (cm) & Leaf number/plant & Leaf length (cm) & Shaft length (cm) \\
\hline 0 & $44.82^{\mathrm{d}}$ & $8.939^{d}$ & $35.07^{d}$ & $5.491^{c}$ \\
\hline 40 & $46.41^{\mathrm{c}}$ & $9.549^{c}$ & $36.45^{\mathrm{c}}$ & $5.701^{\mathrm{b}}$ \\
\hline 80 & $47.79^{b}$ & $10.209^{b}$ & $37.69^{b}$ & $6.166^{\mathrm{a}}$ \\
\hline 120 & $48.37^{a}$ & $10.476^{\mathrm{a}}$ & $38.08^{a}$ & $6.221^{\mathrm{a}}$ \\
\hline SE $( \pm)$ & 0.245 & 0.1260 & 0.259 & 0.0324 \\
\hline CV (\%) & 2.78 & 3.71 & 4.73 & 3.74 \\
\hline
\end{tabular}

Table 4. Mean effect of potassium on onion bulb diameter, length and mean bulb weight.

\begin{tabular}{|c|c|c|c|}
\hline Treatments Potassium (kg ha-1) & Bulb length (cm) & Bulb diameter (cm) & Mean bulb weight (g) \\
\hline 0 & $5.32^{\mathrm{b}}$ & $4.53^{\mathrm{b}}$ & $40.94^{c}$ \\
\hline 40 & $5.45^{\mathrm{b}}$ & $4.63^{b}$ & $44.72^{\mathrm{b}}$ \\
\hline 80 & $5.74^{\mathrm{a}}$ & $4.90^{\mathrm{ab}}$ & $47.25^{\mathrm{a}}$ \\
\hline 120 & $5.82^{\mathrm{a}}$ & $5.07^{a}$ & $48.41^{\mathrm{a}}$ \\
\hline LSD (0.05) & 0.232 & 0.202 & 1.791 \\
\hline CV (\%) & 8.89 & 9.01 & 8.45 \\
\hline
\end{tabular}


In similar manner, [24] also indicated that Onion dry matter production, bulb size and bulb yield increased with the increase in levels of $\mathrm{K}$ from 0 to $150 \mathrm{~kg} \mathrm{ha}^{-1}$. A study [29] again reported that a significantly higher yield of bulb $\left(247.79 \mathrm{q} \mathrm{ha}^{-1}\right)$ and fresh weight of bulbs $(49.53 \mathrm{~g})$ with application of $150 \mathrm{~kg} \mathrm{~K}_{2} \mathrm{O} \mathrm{ha}$ over other potassium levels.

Total bulb yield: With regard to total bulb yield of onion per hectare, there was a highly significant $(\mathrm{P}<0.001)$ variation attributable to the application of $\mathrm{K}$. The results depicted in Table 5 indicates that all the treatment levels the maximum application of $\mathrm{K}$ at the rate of $120 \mathrm{~kg} \mathrm{ha}^{-1}$ significantly increased the total bulb yield when compared with the lower levels and control. This finding is correlated with the findings of a study [26] reported that the higher number of leaves per plant (11.56, 11.68), weight of bulb (50.42 from $51.83 \mathrm{~g})$ and bulb yield (226.66 from $227.66 \mathrm{q} / \mathrm{ha}$ ) with increase in Potassium application from 100 to $150 \mathrm{~kg} \mathrm{ha}^{-1}$.

Unmarketable bulb yield: The application of $\mathrm{K}$ at different levels had shown a highly significant $(\mathrm{P}<0.001)$ difference in terms of unmarketable bulb yield (Table 5 ). The results indicate that higher rate application of $\mathrm{K}$ decreased the unmarketable bulb yield per hectare. Among all treatment levels the highest unmarketable bulb yield was recorded in the unfertilized plots. The lowest unmarketable bulb yield and its best physical properties achieved with increasing rate of potassium application might be attributed to many vital roles of potassium in plant nutrition. There is also a report that application of Potassium at $125 \mathrm{~kg} \mathrm{ha}^{-1}$ recorded significantly highest plant height, total dry matter production which was on par with $150 \mathrm{~kg} \mathrm{ha}^{-1}$. Same treatment recorded significantly higher bulb weight $(106.44 \mathrm{~g} /$ plant), bulb length $(4.68 \mathrm{~cm})$, bulb diameter $(5.32 \mathrm{~cm})$ and bulb yield $(22.87 \mathrm{t} / \mathrm{ha})$ over control [31].

Harvest index: The results given in Table 5 above indicated that application of $\mathrm{K}$ had produced a highly significant $(\mathrm{P}<0.001)$ variation in respect of the harvest index of onion plants. A close analysis of the data further indicates that increasing the level of $\mathrm{K}$ application from 0 to $120 \mathrm{~kg} \mathrm{ha}^{-1}$ highly and significantly

Table 5. Effect of potassium fertilizers on marketable, unmarketable, total yield and harvest index.

\begin{tabular}{|c|c|c|c|c|}
\hline $\begin{array}{c}\text { Treatments } \\
\text { Potassium }\left(\mathrm{kg} \mathrm{ha}^{-1}\right)\end{array}$ & $\begin{array}{c}\text { Marketable } \\
\text { bulb yield/ha }\end{array}$ & $\begin{array}{l}\text { Unmarketable } \\
\text { bulb yield/ha }\end{array}$ & $\begin{array}{l}\text { Total bulb } \\
\text { yield/ha }\end{array}$ & $\begin{array}{c}\text { Harvest } \\
\text { index }\end{array}$ \\
\hline 0 & $12.96^{\mathrm{d}}$ & $0.9133^{a}$ & $13.87^{\mathrm{d}}$ & $0.69^{c}$ \\
\hline 40 & $14.15^{c}$ & $0.7983^{b}$ & $14.95^{c}$ & $0.74^{b}$ \\
\hline 80 & $15.36^{b}$ & $0.6439^{c}$ & $16.01^{b}$ & $0.74^{b}$ \\
\hline 120 & $16.26^{a}$ & $0.5103^{d}$ & $16.78^{a}$ & $0.78^{a}$ \\
\hline SE $( \pm)$ & 0.097 & 0.01493 & 0.093 & 0.020 \\
\hline $\mathrm{CV}(\%)$ & 3.47 & 5.15 & 3.48 & 5.88 \\
\hline
\end{tabular}

*Means in a column followed by the same letter (s) are not significantly different at $5 \%$.

Table 6. TSS of onion bulbs as influenced by application of potassium at different levels.

\begin{tabular}{|c|c|}
\hline Treatments Potassium $\left(\mathbf{k g ~ h a} \mathbf{~}^{-1}\right)$ & Total soluble solid (' ${ }^{\circ}$ brix) \\
\hline 0 & 9.02 \\
\hline 40 & 9.74 \\
\hline 80 & 10.22 \\
\hline 120 & 10.22 \\
\hline SE $( \pm)$ & 0.0262 \\
\hline CV $(\%)$ & 4.41 \\
\hline
\end{tabular}

increased the harvest index. Maximum harvest index (0.78) was observed at $\mathrm{K}$ rate of $120 \mathrm{~kg} \mathrm{ha}^{-1}$ and the lowest mean value (0.69) was recorded from the unfertilized plot. The results from this study showed that increasing the level of $\mathrm{K}$ application increases the harvest index of the onion plants.

\section{Quality parameters}

Total soluble solid (TSS): Regarding the total soluble solid (TSS), the application of K had shown a significant difference (Table 6).

The highest TSS value $\left(10.22^{\circ} \mathrm{Brix}\right)$ was recorded as a result of the application of $\mathrm{K}$ at the rate of $120 \mathrm{~kg} \mathrm{ha}^{-1}$; while the minimum TSS value $\left(9.03^{\circ} \mathrm{Brix}\right)$ was recorded in control.

Bulb shape index: Onion bulb shape index is a function of variety and growth environment. It is vary from flat to globe to torpedo which has different requirements in different markets. The onion bulb shape was assessed by the bulb shape index; this was determined by the ratio of bulb length to diameter. The result of this study revealed that application of $\mathrm{K}$ at different levels independently resulted in a highly significant $(\mathrm{P}<0.001)$ difference on the bulb shape index (Table 7). This result also showed that the null and lower application of $\mathrm{K}$ fertilizers increased the percentage of shape rejects as compared to the plots that received higher levels of K $\left(120 \mathrm{~kg} \mathrm{~K} \mathrm{ha}^{-1}\right)$. Similarly, there is a report that as bulb shape of onion as affected by mineral nutrients [43].

Among the levels, higher application of K $\left(120 \mathrm{~kg} \mathrm{ha}^{-1}\right)$ increased the bulb shape index by about and $2.5 \%$ as compered with control (Table 7). Similar results reported that bulb shape to be different among onion cultivars and was affected by growing environment and that globe shaped bulbs (shape index=1) are preferred by the consumers $[44,45]$.

Dry matter contents: Regarding the dry matter contents, application of $\mathrm{K}$ unilaterally resulted in a highly significant effect. The increasing levels of $\mathrm{K}$ encouraged bulbs with a significantly higher dry matter contents as compared to the unfertilized plot. The maximum dry matter content of onion bulbs $(10.42 \%)$ was recorded with application of $\mathrm{K}$ at higher rates of $120 \mathrm{~kg} \mathrm{ha}^{-1}$. On the other hand, the minimum dry matter content $(9.20 \%)$ was detected in controls for K (Table 7). Similar result is reported that an increase in the doses of $\mathrm{K}$ from $70 \mathrm{~kg}$ $\mathrm{ha}^{-1}$ to $110 \mathrm{~kg} \mathrm{ha}^{-1}$ increased the dry matter content of bulbs from $14.6 \%$ to $15.5 \%$ [25]. There is also another reports that indicates Onion dry matter production, bulb size and bulb yield increased with the increase in levels of $\mathrm{K}$ from 0 to $150 \mathrm{~kg} \mathrm{ha}^{-1}$ [24].

Table 7. Bulb shape index and dry matter contents as affected by Potassium fertilizers.

\begin{tabular}{|c|c|c|}
\hline Treatments Potassium (kg ha-1) & Bulb shape index & Dry matter contents (\%) \\
\hline 0 & $0.84^{b}$ & $9.20^{\mathrm{d}}$ \\
\hline 40 & $0.85^{\mathrm{ab}}$ & $9.78^{\mathrm{c}}$ \\
\hline 80 & $0.85^{\mathrm{ab}}$ & $10.23^{b}$ \\
\hline 120 & $0.87^{a}$ & $10.42^{\mathrm{a}}$ \\
\hline $\operatorname{LSD}_{(0.05)}$ & 0.021 & 0.18 \\
\hline $\mathrm{CV}(\%)$ & 5.15 & 3.82 \\
\hline
\end{tabular}

*Means in a column followed by the same letter (s) are not significantly different at $5 \%$ 


\section{Storage life of onion bulb}

Bulbs storage rots percentage: $\mathrm{K}$ application had a highly significant effect on bulb rotting percentage during the storage time (Table 8). The findings indicated that the application of $\mathrm{K}$ at the maximum rate $\left(120 \mathrm{~kg} \mathrm{ha}^{-1}\right)$ significantly decreased bulb rot percentage which is about $53.5 \%$ when compared with the unfertilized plots. This finding is in harmony with the reports of rotting of bulbs reduced considerably during storage in the bulbs produced by the application of $100 \mathrm{~kg} \mathrm{~K}_{2} \mathrm{O} \mathrm{ha}{ }^{-1}$ [23].

Physiological bulb weight loss percentage: Application of $K$ at different levels had a highly significant $(\mathrm{P}<0.001)$ effect on the weight loss percentage of onion bulb during the storage. The results from Table 8 above indicated that $\mathrm{K}$ application decreased the weight loss of the bulb. K application at the rate of $80 \mathrm{~kg} \mathrm{ha}^{-1}$ showed a significantly lower weight loss as compared to the unfertilized plots. However, further application of $\mathrm{K}$ above 80 $\mathrm{kg} \mathrm{ha}^{-1}$ had no significant effect on bulb weight loss percentage. The results of the present study are in alignment with the reports that loss in total weight was reduced considerably during storage in the bulbs produced by the application of $100 \mathrm{~kg} \mathrm{~K}_{2} \mathrm{O} \mathrm{ha}^{-1}$ [23].

Bulb sprouts percentage and weeks to $50 \%$ bulb sprouts: Sprouting is a physiological change that occurs in onion bulbs during storage. $\mathrm{K}$ application had shown a significant $(\mathrm{P}<0.001)$ difference on percentage of bulb sprouts; $\mathrm{K}$ application had a significant effect on weeks to $50 \%$ bulb sprouts (Table 8 ). In this regard the maximum sprout of bulb was recorded with control treatment, while the minimum sprouts occurred in bulbs which were collected from plots fertilized with the $\mathrm{K}$ at the rate of $40 \mathrm{~kg}$ $\mathrm{ha}^{-1}$. However, further application of $\mathrm{K}$ had no significant effect on the bulb sprouts percentage. Similar results also reported that the lowest sprouting (20.00\%) with application of $\mathrm{K}$ at $180 \mathrm{~kg}$ $\mathrm{ha}^{-1}$ compared to control and sprouting of bulbs in storage had declined with successive increase of $\mathrm{K}[25,46]$.

Keeping Onions for longer duration without sprouting and decay is a big challenge along the commodity chain. In the present study, the results of storage study pertaining to weeks to $50 \%$ bulb sprout revealed that as the amount of $\mathrm{K}$ applied in the field increased, the weeks to attain $50 \%$ bulb sprouts was also extended. Among the levels studied, $\mathrm{k}$ application at maximum rate $\left(120 \mathrm{~kg} \mathrm{ha}^{-1}\right)$ increased the weeks to attain $50 \%$ bulb sprouts by about 1.3 weeks as compared to the unfertilized plots. This result is in line with the finding that sprouting of bulbs in storage had declined with successive increase of $\mathrm{K}$ fertilizer application [46-49].

\section{Discussions}

As to general discussion, the results of the study above showed that application of $\mathrm{K}$ had considerable influence on different parameters. All growth and yield properties as well as storage life of the bulbs showed significant differences due to the treatments applied. The result of the experiment indicated that bulb yield and quality of Bombay Red onion variety was significantly affected by various applications of $\mathrm{K}$. like higher bulb diameter $(5.82$ $\mathrm{cm})$ was recorded at higher level of K (80 kg/ha) application; higher bulb length $(5.07 \mathrm{~cm})$ was recorded at higher level of $\mathrm{K}$ (120 kg/ha) application; higher mean bulb weight (48.41 g) was recorded at higher level of $\mathrm{K}(80 \mathrm{~kg} / \mathrm{ha})$ application; lower unmarketable bulb yield ( $0.51 \mathrm{ton} / \mathrm{ha})$ was recorded at higher level of K (120 kg/ha) application; higher harvest index $(0.78 \%)$ was recorded at higher level of $\mathrm{K}(120 \mathrm{~kg} / \mathrm{ha})$ application and higher dry matter content $(10.42 \%)$ was recorded at higher level of $\mathrm{K}(120 \mathrm{~kg} / \mathrm{ha})$ application were recorded. Finally, maximum (120 $\left.\mathrm{kgha}^{-1}\right)$ application of potassium significantly decreased bulb rots $(2.05 \%)$, bulb weight loss $(34.99 \%)$ and prolonged weeks to $50 \%$ bulb sprout during the two month storage time at ambient storage temperature and humidity and application of $\mathrm{K}$ at $80 \mathrm{~kg} /$ ha lower bulb sprouts percentage $(7.59 \%)$ as compared with the others.

Generally, all the physical and chemical properties as well as storage life of the bulbs showed a significant differences due to the treatment applied and the results of these experiments indicated that as growth, yield, quality and storage life of Bombay Red onion plants significantly affected by applications of $\mathrm{K}$ at different levels.

\section{Summary and Conclusions}

Onion (Allium cepa L.) is introduced to the agricultural community of Ethiopia in the early 1970's when foreigners brought it in. Currently, the crop is produced at different parts of the country for local consumption. Ethiopia increased onion yield and seed production potential in recent years. Optimum levels practices varies with environment, purpose of the production and variety. Hence, there is no specific recommended agronomic practice including fertilizer rate and type to the study area.

The results of the study showed that application of $\mathrm{K}$ had considerable influence on different parameters. All growth and yield properties as well as storage life of the bulbs showed significant differences due to the treatments applied. The result of the experiment indicated that growth, yield, quality and storage life of Bombay Red onion plants was significantly affected by various applications of K. Plant height, leaf diameter, leaf length, number leaves per plant, leaf sheath length, bolters percentage, days to physiological maturity, harvest index, mean bulb weight, bulb length, bulb diameter, TSS ( ${ }^{\circ}$ Brix), DMC (\%) and bulb shape index. Similarly, keeping quality of the onion bulbs like bulb sprouts (\%), weight loss (\%), weeks to $50 \%$

Table 8. Storage rots (\%), bulb weight loss (g) and bulb sprout (\%) as affected by Potassium fertilizers.

\begin{tabular}{|c|c|c|c|}
\hline Treatments Potassium (kg ha-1) & Storage rots of bulbs & PWL & Bulb sprouts percentage \\
\hline 0 & $19.44\left(4.41^{\mathrm{a}}\right)$ & 36.39 a & $66.11\left(8.11^{\mathrm{a}}\right)$ \\
\hline 40 & $10.00\left(3.07^{b}\right)$ & $36.27^{\mathrm{a}}$ & $59.72\left(7.72^{b}\right)$ \\
\hline 80 & $7.22\left(2.50^{c}\right)$ & $35.54^{\mathrm{ab}}$ & $58.89\left(7.59^{b}\right)$ \\
\hline 120 & $5.56\left(2.05^{d}\right)$ & $34.99^{b}$ & $57.72\left(7.66^{b}\right)$ \\
\hline $\operatorname{LSD}_{(0.05)}$ & 0.42 & 0.92 & 0.202 \\
\hline CV $(\%)$ & 30.08 & 5.5 & 5.55 \\
\hline
\end{tabular}


bulb sprouts and storage rots (\%) were highly influenced by application of $\mathrm{K}$ at different levels. The highest total bulb yield per hectare $(18.78 \mathrm{t} / \mathrm{ha})$ was recorded with the plot that received the maximum applications of $\mathrm{K}\left(120 \mathrm{kgha}^{-1}\right)$. Maximum (120 $\mathrm{kgha}^{-1}$ ) application of potassium significantly decreased bulb rots (\%), bulb sprouts (\%), weight loss (\%) and prolonged weeks to $50 \%$ bulb sprout during the two month storage time at ambient storage temperature and humidity.

\section{Future Prospective}

1. Multi-location experiments and similar field and economic feasibility studies need to be carried out for a number of seasons in different soils.

2. Combined experiments with other organic fertilizers in the same field may reflect the sustainability of this practice.

3. Optimization of fertilizers with planting density and water requirement for the different varieties under different agro-ecological condition to understand their yield performance.

\section{References}

1. Randle WM, Ketter CA. Pungency assessment in onions. Proceedings of the19 workshop conference of the Association for Biology Laboratory Education (ABLE). 1998:177-196.

2. Astley D. Innes NL, Van der Meer QP. Genetic resources of Allium species: A global report. International Board for Plant Genetic Resources, Rome. 1982.

3. FAO. Production year book. Food \& Agriculture Organization of United Nations, Rome, Italy. 2008.

4. Chung B. Irrigation and bulb onion quality. Acta horticulture. 1989;247:233-7.

5. Marschner H. Mineral Nutrition of Higher Plants, 2nd ed. Academic press. London. 1995:196.

6. Bungard RA, Wingler A, Morton JD, et al. Ammonium can stimulate nitrate and nitrite reductase in the absence of nitrate in Clematis vitalba. Plant Cell Environ. 1999;22:859-66.

7. Archer J. Crop Nutrition and Fertilizer Use. Second Edition. Farming Press Ltd.Wharfedaale Road, Ipswich, Suffolle. Sharma, J.P. and Aggarwal, B. (2002). Sulphur - A boon in agriculture. Intensive Agriculture. 1988;2:30-2.

8. Murphy HF. A Report on Fertility Status of Some Soils of Ethiopia. HSIU/College of Agriculture. Alemaya. Experiment Station Bull No. 44. 1968.

9. Wassie H, Shiferaw B. Mitigation of soil acidity and Fertility decline challenges for sustainable livelihood improvement: research findings from souther region of ethiopia and its policy implications. Conference: Proceedings of the national Conference on Sustainable Land Management and Poverty Alleviation, Coorganized by Environmental Economics Policy Forum for Ethiopia at Ethiopian Development Research Institute, Sustainable Land Use Forum (SLUF),
Oromia Agricult. 2009:131-43.

10. Raja MB, Khokhar KM. Postharvest horticulture technology and its future prospects. In: Proceeding of first international horticulture seminar. Pakistan Agriculture Council, Islamabad. 1993:265-77.

11. Hayden NJ. Observations on harvesting and storing onions in northern Sudan. Onion Newsletter for Tropics. 1989;1:19-23.

12. Denton L, Ojeifo IM. Onion production practices and their improvement in Nigeria. Onion Newsletter for the Tropics. 1990;2:10-3.

13. Kabir A. Rising onion prices. Dawn Internet edition. 2007.

14. Murashkina M, Southard RJ, Pettygrove GS. Potassium Fixation in Silt, Sand and Clay Fractions of Soils Derived from Granitic Alluvium of the San Joaquin Valley, California. 18th World Congress of Soil Science (July 9-15, 2006) at Philadelphia, Pennsylvania, USA. 2006.

15. Brewster JL. Onions and Other Vegetable Alliums. CABI Publishing. Wallingford, UK. 1994.

16. Brewster JL, Rabinowitch HD. Onion and allied crops, vol. III. Biochemistry, Food science and Minor Crops. 1989;3:1-298.

17. Kalb T. Onion Cultivation and Seed Production: Training Guide AVRDC. 2001.

18. Lemma D. Onion Production Pamphlet (Amharic version). EARO, Melkassa Research Center. 2004.

19. Ethiopian agricultural research organization (EARO). Directory of released crop varieties and their management. Addis Ababa. Ethiopia. 2004.

20. MoARD. Crop Variety Register. Crop Development department, Issue No.9, June 2006, Addis Ababa, Ethiopia. 2006.

21. AGL. Crop Water Management: Onion. FAO [retrieved, 12, March 2008]. 2002.

22. Madan MR, Sandhu N. Economic analysis of nitrogen, phosphorus and potassium fertilization in onion. Haryana $\mathrm{J}$ Hort Sci. 1983;12:221-3.

23. Singh J, Dankhar BS. Effect of nitrogen, potash and zinc on storage loss of onion bulbs (Allium cepa L.). Vegetable Science. 1991;18:16-23.

24. Salimath, SS. Studies on status of potassium and sulphur in soils and their effect on onion (Allium cepa L.). M. Sc. (Agri) Thesis, University of Agricultural Sciences, Dharwad. 1990.

25. Nandi RK, Deb M, Maity TK, et al. 2002, Response of onion to different levels of irrigation and fertilizer. Crop Research. 2002;23(2):317-20.

26. Vachhani MU, Patel ZG. Effect of nitrogen, phosphorus and potash on bulb yield and quality of onion (Allium cepa L.). Indian Journal of Agronomy.1993;38:333-4.

27. Kumar A, Ranbir Singh, Chhillar RK. Influence of nitrogen 
Citation: Bekele M. Effects of different levels of potassium fertilization on yield, quality and storage life of onion (Allium cepa L.) at Jimma, Southwestern Ethiopia.. J Food Sci Nutr. 2018;1(2):32-9.

and potassium application on growth, yield and nutrient uptake by onion (Allium cepa. L). Indian J. Agron. 2001;46(4):742-6.

28. Sharma RP, Dati N, Sharma PK. Combined application of $\mathrm{N}, \mathrm{P}, \mathrm{K}$ and FYM in onion (Allium cepa L.) under high hills, dry temperature conditions of north western Himalayas. Indian J Agric Sci. 2002;3(1):258-60.

29. Yadav RL, Sen NL, Fageria MS, et al. Effect of nitrogen and potassium fertilization on quality bulb production of onion. Haryana Journal of Horticultural Science. 2002;31(3\&4):297-8.

30. Tiwari RS, Agarwal A. Influence of N, P, K levels on yield of garlic (Allium sativum L.). J. Pot. Res. 2003;19:119-23.

31. Hariyappa N. Effect of potassium and sulphur on growth, yield and quality parameters of onion (Allium cepa L.). M. Sc. (Agri.) Thesis, University of Agricultural Sciences, Dharwad. 2003.

32. Anwar MN, Sarker JU, Rahman M, et al. Response of onion to nitrogen, phosphorus, potassium, sulphur and zinc. Bangladesh Journal of Environmental Science. 2001;7:68-72.

33. Haggag MEA, Rizk MA, Hagras AM, et al. Effects of P, K, and $\mathrm{N}$ on yield and quality of onion. Annals of Agricultural Science. 1986;31:989-1010.

34. Thompson LM. Troeh FH. Soils and Soil fertility. McGr aw-Hi 1 1, New York. 1978.

35. Getachew, Asfaw. Ethiopian Agricultural Research Organization: Achievements in shallot and garlic. Research report No.36. Addis Ababa. 2009.

36. Al-Karaki. Growth, sodium, and potassium uptake and translocation in salt stressed tomato. J Plant Nutrition. 2000;23(3):369-79.

37. El-Bassiouny AM. Effect of potassium fertilization on growth, yield and quality of onion plants. Journal of Applied Science Research. 2006;2(10):780-5.

38. Fawzy ZF, Behairy AG, Shehata SA. Effect of potassium fertilizer on growth and yield of sweet pepper plants (Capsicum annuum, L.). Egypt Journal of Agricultural Research. 2005;2(2):599-610.

39. Gupta CR, SS Sengar. Response of tomato (Lycopersicon esculentum Mill.) to nitrogen and potassium fertilization in acidic soil of Bastar. Veg Sci.2000;27(1):94-5.

40. Nanadal JK, Ramesh-Vasist, Pandey UC. Effect of phosphorus and potassium on growth yield and quality of tomato. J Potassium Research. 1998;14(1/4):44-9.

41. Nassar HH, Barakat MA, El-Masry TA, et al. Effect of potassium fertilization and paclobutrazol foliar application on vegetative growth and chemical composition of sweet pepper. Egypt Journal of horticulture. 2001;28(1):113-29.

42. Pettigrew WT. Potassium influences on yield and quality production for maize, wheat, soybean and cotton (electronic resource). Physiologia plantarum. 2008;133(4): 670-81.
43. Geremew A. Effect of intra-row spacing on yield of three onion (Allium cepa 1.) varieties at Adami Tulu agricultural research center. Journal of Horticulture and Forestry. 2009;2(1):7-11.

44. Kimani PM, Karinki JW, Peters R. et al. Influence of environment on the performance of some onion cultivars in Kenya. African Crop science Journal. 1993;1(1):15-23.

45. Mojsevich, NV. Influence of fertilizers on yielding capacity and quality of annual onion crops. Ovoshchevodstvo (Belarus) no. 15. 2008.

46. Masalkar SD, Lawande KE, Patil RS, et al. Effect of potash levels and seasons on storage behavior of onion 'Phule Safed'. 4th International Symposium on edible Alliaceae. International Society for Hort. Sci. Acta Hort. (ISHS). 2005;688:225-8.

47. Greenwood DJ, Stone DA. Prediction and measurement of the decline in critical-K, the maximum $\mathrm{K}$ and total plant cation concentration during the growth of field vegetable crops. Annals of Botany. 1998;82:871-81.

48. Lester GE, Jifon JL, Makus DJ. Supplemental foliar potassium applications with or without a surfactant can enhance netted muskmelon quality. Hort Science. 2006;41(3):741-4.

49. Williams L, Kafkafi U. In: El-Fouly MM, Abdalla FE, Abdel-Maguid AA (eds.). Proceedings of the symposium on foliar fertilization: A technique to improve production and decrease pollution, 10-14 Dec. 1995, NRC, Cairo. 1998;85-90.

\section{*Correspondence to:}

Muluneh Bekele Etana

Department of Horticulture

College of Agriculture

Samara University

Samara,

Ethiopia

Tel: +251-0913090793

E-mail: muluneh.b2002@yahoo.com 